Sari Pediatri, Vol. 7, No. 2, September 2005: 85 - 92

\title{
Kecerdasan Majemuk pada Anak
}

\author{
Kadek Suarca, Soetjiningsih, IGA. Endah Ardjana
}

\begin{abstract}
Kecerdasan majemuk pertama kali diperkenalkan tahun 1983 oleh Howard Gardner di Harvard School of Education and Harvard Project Zero. Teori ini membantah tes seperti contoh Stanford Binet Test yang dikatakan sebagai hitungan tradisional yang tidak adekuat menilai kecerdasan. Menurut Gardner, kecerdasan melebihi dari hanya sekedar IQ (Intelligence Quotient) karena IQ yang tinggi tanpa ada produktifitas bukan merupakan kecerdasan yang baik. Anak harus dinilai berdasarkan apa yang mereka dapat kerjakan bukan apa yang tidak dapat mereka kerjakan. Kecerdasan didefinisikan sebagai kemampuan untuk memecahkan masalah dan memiliki nilai lebih dalam sebuah kultur masyarakat. Kecerdasan adalah potensi biopsikologikal untuk mengolah informasi sehingga dapat memecahkan masalah, menciptakan hasil baru yang menambah nilainilai budaya setempat. Pandangan baru ini sangat berbeda dengan pandangan lama yang selalu mengandalkan dua penilaian yaitu verbal dan komputasional. Delapan macam kecerdasan itu antara lain, (1) Kecerdasan linguistik, (2) Kecerdasan logika-matematika, (3) Kecerdasan gerak tubuh, (4) Kecerdasan musikal, (5) Kecerdasan visual-spasial, (6) Kecerdasan interpersonal, (7) Kecerdasan intrapersonal, dan (8) Kecerdasan naturalis.
\end{abstract}

Kata kunci: kecerdasan majemuk, Intelligence Quotient (IQ).

X ecerdasan ${ }^{1}$ pada mulanya diartikan dalam bahasa sehari-hari sebagai kemampuan untuk menyelesaikan persoalan-persoalan praktis, ${ }^{1}$ dan terdapat persepsi bahwa kemampuan untuk belajar berasal dari kapasitas kognitif. Selanjutnya, makna ini harus diperluas dan lebih fundamental karena pada dasarnya kecerdasan dan aspek kognitif tak terpisahkan dari aktifitas pikiran atau kesadaran manusia secara utuh dalam hubungannya dengan aspek-aspek diri manusia seutuhnya serta interaksinya dengan lingkungannya. ${ }^{1,2}$ Alfred Binet pada tahun 1905 dan ${ }^{1911}$ meneliti cara mengukur

\footnotetext{
Alamat korespondensi:

Dr. Kadek Suarca, Prof. dr. Soetjinigsih, SpA(K), IBCLC,

Dr. IGA Endah Ardjana, SpKJ

Bag/SMF Ilmu Kesehatan Anak Fakultas Kedokteran Univ. Udayana/

RS Sanglah, Denpasar

Jl. Pulau Nias Denpasar Bali

Telp/Fax. 0361-244038/224556
}

inteligensia dengan membuat formula suatu tes untuk mengukur kapasitas belajar yang disebut sebagai Intelligence Quotient atau tes IQ. Kemudian psikolog LM Terman (1877-1956) dari Stanford, Amerika Serikat mengadaptasi dan menstandardisasi tes IQ tersebut pada anak-anak di Amerika pada tahun 1916, yang kemudian disebut sebagai tes Stanford-Binet. David Wechsler (1939) membuat Wechsler Adult Intelligence Scale (WAIS) dan telah direvisi berkali-kali sebagai WAIS-R dan Wechsler Intelligence Scale for Children-R (WISC-R). ${ }^{1-4}$ Tes Binet pada dasarnya mengetahui kemampuan intelektual siswa dalam jangka pendek, tetapi ternyata digunakan juga untuk menentukan ranking siswa. Hasil tes IQ hanya mempunyai kontribusi 25\% terhadap kemampuan seseorang yang sesungguhnya dan IQ hanya berkontribusi 30\% dalam prestasi kerja seseorang. ${ }^{2,4}$

Howard Gardner di Harvard School of Education and Harvard Project Zero tahun 1983 telah mencetuskan teori kecerdasan majemuk yang menolak teori 
lama tentang kecerdasan dan mengatakan bahwa tes seperti tes Stanford Binet atau SAT untuk ujian masuk sebuah sekolah sebagai hitungan tradisional yang tidak adekuat menilai kecerdasan atau ketangkasan. Anakanak harus dinilai dari apa yang dapat mereka lakukan bukan menilai bagaimana mereka dapat melakukan. Teori kecerdasan majemuk adalah cara untuk mengerti kecerdasan melalui beberapa aspek (pluralized way to understanding intellect) $)^{2,7,8}$ yang meliputi 8 jenis kecerdasan yang terdiri dari kecerdasan linguistik, kecerdasan logika-matematika, kecerdasan visual spasial, kecerdasan gerak tubuh, kecerdasan musikal, kecerdasan interpersonal, kecerdasan intrapersonal, dan kecerdasan naturalis. ${ }^{2-12}$

\section{Peranan Otak Dalam Kecerdasan}

Menurut teori The Triune Brain Model yang diperkenalkan oleh Dr Paul MacLean dinyatakan bahwa lapisan otak manusia sebenarnya merupakan perkembangan evolusi tiga tingkat kehidupan yaitu reptilian brain, limbic brain dan neokorteks (the thinking brain). Neokorteks merupakan lapisan paling muda dan berada paling luar dari kedua lapisan tersebut., ${ }^{5,13}$ Bagian reptilian brain bertanggung jawab terhadap fungsi sensorik dan pengontrol fungsi organ vital. Limbic brain bertanggung jawab terhadap hal yang bersifat kognitif dan emosional, dan tempat untuk menyimpan perasaan kita, pengalaman manusia yang menyenangkan, memori manusia, kemampuan belajar manusia, dan juga mengatur bioritme manusia. Neokorteks membentuk 80\% dari seluruh masa otak dan terbungkus di bagian atas dan sisi sistem limbik. Menurut Dr Roger Sperry dikutip dari Pangalila ${ }^{14}$, kedua belahan korteks merupakan lokasi dari fungsi intelektual tertentu. Neokorteks mengatur pesan yang diterima melalui penglihatan, pendengaran dan sensasi tubuh serta mengatur penalaran, berfikir secara intelektual, pembuatan keputusan, perilaku waras, bahasa, kendali motorik sadar dan penciptaan gagasan non verbal. ${ }^{5,13,14}$

Neokorteks dibagi menjadi belahan hemisfer kiri dan kanan. Belahan otak kiri mengatur badan, mata, dan telinga bagian kanan. Bagian ini berperan dominan dalam berfikir logika dan rasional, menganalisis, berbicara (bahasa) serta berorientasi pada waktu dan hal-hal yang terinci. Belahan otak kanan mengontrol badan, mata dan telinga bagian kiri. Otak kanan mengendalikan pikiran bawah sadar dan emosi, dan hal-hal yang intuitif (imajinasi) berupa lamunan maupun visualisasi, kesadaran spasial seperti dimensi atau gambaran global, warna, merasakan, bermusik (irama), menari, melakukan hal-hal reaktif, dan sebagainya. ${ }^{5,6,14}$ Orang yang memanfaatkan kedua belahan otak ini cenderung seimbang dalam setiap aspek kehidupannya. ${ }^{5}$

Persambungan antar sel-sel otak (neuron) sangat penting bagi perkembangan mental seseorang, karena merupakan kekuatan dasar utama dari terjaminnya pengembangan proses belajar dan pengembangan potensi mental seluruh hidup pemiliknya. Makin banyak dan luas neuron yang saling berhubungan maka semakin banyak asosiasi yang dapat dibentuk dan kombinasi yang dibentuk. Ini membuat anak semakin cerdas dan kreatif. ${ }^{14}$

\section{Pengertian Kecerdasan}

Dalam pandangan lama ada beberapa pengertian tentang kecerdasan. Kecerdasan menurut Steven J. Gould dari Harvard (1994) adalah kapasitas mental umum yang meliputi kemampuan untuk memberikan alasan, membuat rencana, memecahkan masalah, berpikir abstrak, menghadapi ide yang kompleks, belajar dari pengalaman, dan dapat diukur dengan tes IQ yang tidak dipengaruhi oleh budaya dan genetik yang berperan besar. Secara bertahap IQ distabilkan selama masa anak, dan setelah masa itu hanya sedikit perubahannya. ${ }^{2,3}$, Menurut David Wechsler, inteligensi adalah suatu kemampuan mental yang melibatkan proses berfikir secara rasional. Oleh karena itu inteligensi tidak dapat diamati secara langsung melainkan harus disimpulkan dari berbagai tindakan nyata yang merupakan manifestasi dari proses berfikir rasional itu. ${ }^{15,16}$ Definisi yang mudah dimengerti adalah kemampuan untuk mengerti ide yang kompleks, mampu beradaptasi dengan efektif terhadap lingkungannya, mampu belajar dari pengalaman, mampu melaksanakan tugas dalam berbagai macam situasi, mampu mengatasi hambatan dengan menggunakan pikirannya. ${ }^{3}$

Howard Gardner mengembangkan konsep penilaian kecerdasan melalui kecerdasan majemuk dengan memandang manusia tidak hanya berdasarkan skor standar semata melainkan dengan ukuran kemampuan untuk menyelesaikan masalah yang terjadi 
dalam kehidupan manusia, kemampuan untuk menghasilkan persoalan baru untuk diselesaikan, kemampuan untuk menciptakan sesuatu atau memberikan penghargaan dalam budaya seseorang. ${ }^{2,9,11}$ Kecerdasan majemuk didasari oleh dua hal penting yaitu faktor biologi dan faktor budaya. Dalam studi neurobiologi disebutkan bahwa belajar adalah outcome dari adanya modifikasi yang terjadi pada hubungan sinaps antar sel.

Ada berbagai kecerdasan yang tidak hanya dilihat dari segi linguistik dan logika. Bagi Gardner tidak ada anak yang bodoh atau pintar; yang ada adalah anak yang menonjol dalam salah satu atau beberapa jenis kecerdasan. Dalam menilai dan menstimulasi kecerdasan anak, orangtua dan guru selayaknya dengan jeli dan cermat merancang sebuah metode khusus. Setiap manusia memiliki kecenderungan cerdas di satu bidang tanpa harus bersusah payah mengasahnya. . $^{2,3,5,17-}$ 19

\section{Kecerdasan Linguistik}

Kecerdasan linguistik adalah kemampuan menggunakan kata secara efektif. ${ }^{17,20}$ Pandai berbicara, gemar bercerita dan dengan tekun mendengarkan cerita atau membaca merupakan tanda anak yang memiliki kecerdasan linguistik yang menonjol. ${ }^{17,19}$ Potensi kecerdasan berbahasa yang dimiliki seorang anak hanya akan tinggal potensi bila tidak dilatih atau dikembangkan. Pola asuh sangat berpengaruh dalam hal ini. Anak yang tidak diberi kesempatan berbicara atau selalu dikritik saat mengemukakan pendapatnya akan kehilangan kemampuan dan ketrampilannya dalam mengungkapkan ide dan perasaannya. ${ }^{19}$

Rangsangan dan latihan yang dilakukan terus menerus oleh orang tua dapat mengembangkan ketrampilan berbahasa anak sekalipun ia tidak memiliki kecerdasan linguistik yang tinggi, walaupun hasilnya tidak sebesar bila anak memiliki kecerdasan linguistik yang tinggi. Hal-hal yang dapat dilakukan untuk menstimulasi seperti misalnya mengajak anak berbicara, membacakan cerita, bermain huruf dan angka, merangkai cerita, berdiskusi, bermain peran, memperdengarkan lagu anak-anak dan sebagainya. ${ }^{19}$

Hal-hal yang mungkin didapatkan pada anak dengan kecerdasan linguistik diantaranya seperti suka menulis kreatif di rumah, mengarang kisah khayal atau menuturkan lelucon dan cerita, sangat hafal nama, tempat, tanggal atau hal-hal kecil, menikmati membaca buku di waktu senggang, mengeja kata-kata dengan tepat dan mudah, menyukai pantun lucu dan permainan dengan kata-kata, menikmati mendengar kata-kata lisan, mempunyai kosa kata yang luas untuk anak seusianya, unggul dalam pelajaran sekolah yang melibatkan membaca atau menulis. ${ }^{17}$

\section{Kecerdasan Logika Matematika}

Kecerdasan logika matematika pada dasarnya melibatkan kemampuan untuk menganalisis masalah secara logis, menemukan atau menciptakan rumusrumus atau pola matematika dan menyelidiki sesuatu secara alamiah. Ada juga yang secara awam menjabarkan kecerdasan ini sebagai kecerdasan ilmiah karena berkaitan dengan kegiatan berfikir atau berargumentasi secara induktif dan deduktif, berfikir dengan bilangan dan kesadaran terhadap pola-pola abstrak. Anak yang memiliki nilai tinggi untuk kategori kecerdasan ini suka melakukan eksperimen untuk membuktikan rasa penasarannya antara lain dengan pertanyaan atau aksi eksperimental. Anak yang seperti ini adalah anak yang selalu yakin bahwa semua pertanyaaan memiliki suatu penjelasan rasional yang masuk akal sehingga sering lebih merasa nyaman berhadapan dengan sesuatu yang dapat dikategorisasi, diukur, dianalisa dan ditilik kuantitasnya dalam berbagai cara. Kecerdasan logika matematika juga terkait erat dengan kecerdasan linguistik terutama dalam kaitannya dengan penjelasan alasan-alasan logika.

Menurut Jean Piaget dikutip dari majalah Ayah Bunda $2003^{18}$, proses berfikir seseorang dengan tipe kecerdasan logika matematika di atas rata-rata ini sangat didukung oleh kriteria empiris. Bagian otak tertentu menjadi lebih dominan bekerja saat melakukan kalkulasi matematis dibandingkan dengan bagian otak lainnya. Semakin tinggi tingkat usia seseorang maka kegiatan yang mereka geluti semakin bersifat abstrak, sehingga anak yang memiliki kecerdasan logika matematika yang tinggi biasanya memilih profesi yang mengandalkan abstraksi dan logis simbolis seperti peneliti, pemikir, atau insinyur.

Beberapa kegiatan yang dapat dengan mudah dilakukan pada anak untuk stimulasi kecerdasan ini misalnya menyelesaikan puzzle, mengenal bentuk geometri, memperkenalkan bilangan melalui sajak berirama dan lagu, eksplorasi pikiran melalui diskusi 
dan olah pikir ringan, pengenalan pola, eksperimen di alam, memperkaya pengalaman berinteraksi dengan konsep matematika, menggambar dan membaca dan lainnya.

\section{Kecerdasan Visual Spasial}

Kecerdasan visual-spasial memungkinkan orang membayangkan bentuk geometri atau tiga dimensi dengan lebih mudah karena ia mampu mengamati dunia spasial secara akurat dan mentransformasikan persepsi ini termasuk di dalamnya adalah kapasitas untuk memvisualisasi, menghadirkan visual dengan grafik atau ide spasial, dan untuk mengarahkan diri sendiri dalam ruang secara tepat. Kecerdasan ini juga membuat individu mampu menghadirkan dunia ruang secara internal dalam fikirannya. Cara inilah yang digunakan pelaut atau pilot pesawat terbang ketika mengarungi ruang dunia. Begitu pula bagi seorang pemain catur yang menghadirkan sebuah dunia spasial yang terbatas. ${ }^{19}$

Anak-anak ini tampaknya mengetahui letak semua barang di dalam rumah. Mereka berfikir dalam bentuk visualisasi dan gambar. Merekalah yang paling pertama dapat menemukan barang-barang hilang atau salah taruh. Anak-anak seperti ini akan peka terhadap perubahan interior rumah dengan memberikan reaksi suka atau tidak suka. Banyak diantara mereka mengagumi aneka mesin dan peralatan aneh. Mereka mungkin bisa menjadi arsitek, seniman, montir, insinyur atau perancang kota. Ketrampilan atau kelebihan yang mungkin dimiliki seperti menonjol dalam kelas seni di sekolah, memberikan gambaran visual yang jelas ketika sedang memikirkan sesuatu, mudah membaca peta, grafik dan diagram, menggambar sosok orang atau benda yang persis aslinya, senang melihat film, slide atau foto, menikmati melakukan teka-teki jigsaw, maze atau kegiatan visual lain, sering melamun, membangun konstruksi tiga dimensi yang menarik, mencorat-coret di atas secarik kertas atau di buku tugas sekolah, lebih banyak memahami lewat gambar daripada kata-kata ketika sedang membaca. ${ }^{17}$

\section{Kecerdasan Gerak Tubuh}

Anak dengan kecerdasan gerakan tubuh di atas rata- rata senang bergerak dan menyentuh. Mereka memiliki kontrol pada gerakan, keseimbangan, ketangkasan dan keanggunan dalam bergerak, dan mengeksplorasi dunia dengan otot-ototnya.

Menurut Laurel Schmidt dikutip Amstrong ${ }^{17}$ setiap orang memiliki kemampuan gerak tubuh dan beberapa orang berpendapat bahwa kemampuan mengontrol fisik bukanlah suatu bentuk dari kecerdasan. Namun Gardner dan peneliti lain dalam bidang kecerdasan majemuk mempertahankan pendapatnya. Individu dengan kecerdasan gerakan tubuh secara alamiah memiliki tubuh yang atletis, memiliki ketrampilan fisik, kemampuan dan merasakan bagaimana seharusnya tubuh membentuknya sehingga mahir menggunakan seluruh tubuh untuk mengekspresikan ide dan perasaan. Kecerdasan ini juga termasuk ketrampilan koordinasi, keseimbangan, kelenturan, kekuatan, fleksibilitas dan kecepatan.

Peran otak kanan dan kiri ternyata dapat diaktifkan melalui gerakan tangan dan kaki dalam senam otak. Dengan mengaktifkan kedua belahan otak, integrasi atau kerjasama antar keduanya akan terjadi. Hal ini dimungkinkan, mengingat kedua belahan otak dihubungkan dengan corpus collusum yakni simpul saraf komplek tempat terjadinya transmisi informasi antar belahan otak. Bila sirkuit-sirkuit belahan otak tersebut cepat menyilang maka kemampuan belajar anak bisa dibangkitkan.

Ketrampilan yang dapat dilihat pada anak dengan kecerdasan gerak tubuh antara lain berprestasi dalam bidang olah raga kompetitif, bergerak-gerak ketika sedang duduk, terlibat dalam kegiatan fisik seperti berenang, bersepeda, mendaki dan lain-lain. Mereka perlu menyentuh sesuatu yang ingin dipelajari, menikmati melompat, lari, gulat atau yang serupa lainnya. Anak dengan kecerdasan gerak tubuh juga memperlihatkan ketrampilan dalam bidang kerajinan tangan, pandai menirukan gerakan, kebiasaan, atau perilaku orang lain, sering "merasakan" jawaban masalah yang dihadapi di rumah atau di sekolah, menikmati bekerja dengan tanah liat, melukis dengan jari atau kegiatan kotor lainnya, sangat suka membongkar berbagai benda dan kemudian menyusunnya lagi. ${ }^{17}$

\section{Kecerdasan Musikal}

Anak dengan kecerdasan musikal mudah mengenali dan mengingat nada-nada. Ia juga dapat mentrans- 
formasi kata-kata menjadi lagu dan menciptakan berbagai permainan musik. Merekapun pintar melantunkan bait lagu dengan baik dan benar, menggunakan kosa kata musikal, dan peka terhadap ritme, ketukan, melodi atau warna suara dalam sebuah potongan komposisi musik.

Dalam bukunya, Gardner berpendapat bahwa konsep kecerdasan sebagai potensi biopsikologis untuk memproses informasi yang dapat diaktivasi dalam sebuah budaya untuk memecahkan masalah atau menciptakan produk-produk yang merupakan nilai dalam sebuah budaya. ${ }^{2}$ Kecerdasan musikal dapat diartikan sebagai kemampuan untuk berfikir atau mencerna musik, untuk mampu menyimak pola-pola, mengenalinya dan mungkin mengubah komposisi atau memanipulasinya. Apabila seorang anak tumbuh dan dididik dalam sebuah budaya yang mengagungkan ketrampilan atau kemampuan musik, besar kemungkinan potensi musik anak terasah dan berkembang.

Dengan pemahaman teori Gardner, maka kecerdasan itu tidak hanya dipengaruhi oleh sesuatu yang dibawa sejak lahir namun kecerdasan inipun dapat diasah. Seringkali anak-anak dengan kecerdasan musikal yang sangat menonjol dinilai pendidik dan orangtua sebagai anak yang diberi karunia atau kelebihan sejak lahir; sedangkan bakat membutuhkan latihan serta stimulasi. Namun perlu disadari bahwa talenta atau bakat maupun karunia tidak ada artinya tanpa stimulasi. Meskipun setelah ada stimulasi karunia kemudian membawa pengaruh cukup besar pada prestasi yang dicapai anak. Ketrampilan yang mungkin bisa didapat pada kecerdasan musikal seperti memainkan alat musik di rumah atau di sekolah, ingat melodi lagu, berprestasi sangat bagus di kelas musik di sekolah, lebih bisa belajar dengan iringan musik, mengoleksi $\mathrm{CD}$ atau kaset, bernyanyi untuk diri sendiri atau orang lain, bisa mengikuti irama musik, mempunyai suara yang bagus untuk menyanyi, peka terhadap suara-suara di lingkungannya, dan memberikan reaksi yang kuat terhadap berbagai jenis musik.

\section{Kecerdasan Interpersonal}

Kecerdasan interpersonal adalah kemampuan untuk bisa memahami dan berkomunikasi dengan orang lain, serta mampu membentuk dan menjaga hubungan, dan mengetahui berbagai peran yang terdapat dalam suatu lingkungan sosial. Memiliki interaksi yang baik dengan orang lain, pintar menjalin hubungan sosial, serta mampu mengetahui dan menggunakan beragam cara saat berinteraksi, adalah ciri-ciri kecerdasan interpersonal yang menonjol.

Pada dasarnya, anak-anak akan belajar menyesuaikan diri dengan tuntutan sosial dan menjadi pribadi yang mampu berinteraksi dengan lingkungan sosialnya, hal ini bergantung pada empat faktor. Pertama, faktor kesempatan bersosialisasi. Kedua, mampu menampilkan topik yang dapat dipahami dan menarik bagi orang lain tapi pembicaraan yang bersifat sosial, tidak bersifat egosentrik dan dapat diterima oleh lingkungan sosialnya. Ketiga, anak harus mampunyai motivasi, bergantung pada tingkat kepuasan yang diperoleh dari aktivitas sosial anak. Jika ia memperoleh kesenangan melalui hubungan sosial dengan orang maka iapun akan mengulangi perilaku tersebut. Keempat, metode belajar saat berinteraksi sosial dengan orang lain yang efektif, adalah melalui teladan yang diberi oleh orang tua ataupun pendidik di rumah dan di sekolah.

Salah seorang psikolog dari Inggris, NK Humphrey dikutip dari Amstrong ${ }^{17}$, mengatakan kecerdasan interpersonal yang merupakan bagian dari kemampuan sosial ini, merupakan hal penting dari kecerdasan manusia karena manfaat terbesar dari pikiran manusia adalah untuk mempertahankan kehidupan sosial dengan cara yang efektif.

Dengan memberikan kesempatan anak untuk mengembangkan aspek kecerdasan ini melalui berbagai kegiatan interpersonal, tentunya akan memberi manfaat sangat besar bagi proses tumbuh kembang anak. Apalagi jika hal ini juga ditunjang oleh rangsangan yang diberikan oleh orang tua maupun guru. Anak akan memiliki efek penerimaan sosial yang baik dengan kecerdasan interpersonal yang baik pula; sehingga anak merasa senang dan aman saat berinteraksi di lingkungan sosialnya. Ia lebih mampu mengembangkan konsep diri yang menyenangkan, karena orang lain mengakui keberadaannya.

\section{Kecerdasan Intrapersonal}

Kecerdasan intrapersonal merupakan kemampuan seseorang untuk memahami diri sendiri, mengetahui siapa dirinya, apa yang dapat dilakukan, apa yang ingin ia lakukan, bagaimana reaksi diri terhadap suatu situasi dan memahami situasi seperti apa yang sebaiknya ia 
hindari serta mengarahkan dan mengintrospeksi diri. ${ }^{2}$

Ada kalanya individu sebagai sosok mahluk sosial memiliki keinginan untuk memahami apa yang tengah terjadi pada dirinya, apa yang sedang dirasakan saat itu, atau memahami apa yang dapat ataupun yang ingin dikerjakan pada suatu saat. Dampak dari kegiatan dalam diri ini akan menghasilkan motivasi, empati, etika dan sikap altruisme, mementingkan orang lain, pada diri individu yang bersangkutan. ${ }^{17}$ Tanpa sumbersumber batin ini akan sulit bagi seseorang individu untuk membangkitkan kehidupan yang produktif dan bahagia. ${ }^{17}$ Sebagian besar peneliti meyakini ketika seorang individu lahir ke dunia, kepandaian intrapersonal telah berkembang dari sebuah kombinasi antara keturunan, lingkungan dan pengalaman.

Untuk mengembangkan potensi intrapersonal, lingkungan sekolah dipersiapkan untuk dapat mengorganisasi dan mempertinggi kebanggaan diri pada masing-masing anak. Sekolah diharapkan dapat memotivasi siswa yang memiliki masalah kemampuan pemahaman diri, percaya diri atau penghargaan terhadap diri sendiri dengan memberikan pengajaran berdasarkan program 4A yaitu attention, acceptance, appreciation, affection. ${ }^{13,16,17}$ Para pendidik dapat memberikan rangsangan untuk mengembangkan potensi intrapersonal anak dengan cara menciptakan citra diri positif, menciptakan suasana sekolah yang mendukung pengembangan kemampuan intrapersonal dan penghargaan diri anak, menuangkan isi hati dalam sebuah buku harian, memperbincangkan kelemahan, kelebihan dan minat anak, memberi kesempatan untuk menggambar diri sendiri dari sudut pandang anak, membayangkan diri di masa akan datang, dan mengajak berimajinasi menjadi satu tokoh dari sebuah cerita.

\section{Kecerdasan Naturalis}

Anak dengan kecerdasan naturalis yang tinggi pada usia sangat dini telah memiliki daya tarik yang besar terhadap lingkungan alam sekitar termasuk pada binatang. Di usia yang lebih besar, anak-anak tersebut sangat berminat pada biologi, botani, ilmu hewan, geologi, meteorologi, palentologi atau astronomi.

Ide Gardner tentang kecerdasan naturalis ini baru muncul tahun 1995 dan dipublikasikan tahun 1997. Uraian tentang kecerdasan ini sangat sederhana bahkan hingga sekarang teori tentang cerdas alam ini masih terus dalam proses penyempurnaan. ${ }^{2,9,16,17,19}$ Kecer- dasan naturalis ini pada dasarnya berkaitan dengan kemampuan merasakan bentuk-bentuk serta menghubungkan elemen yang ada di alam.

Di katakan bahwa kecerdasan naturalis tidak ada korelasi langsung yang berhubungan dengan saraf. Namun Leslie Owen Wilson dalam tulisannya The eighth intelligence: naturalistic intelligence (dikutip dari majalah Ayah Bunda 2003), mengatakan bahwa cerdas alam berkaitan dengan wilayah otak yang peka terhadap sensori persepsi, serta bagian otak yang berkaitan dalam membedakan dan mengklasifikasi sesuatu, yaitu otak bagian kiri.

Kecerdasan naturalis adalah kecerdasan yang dimiliki semua orang pada awal kehidupannya. Anak kecil memiliki kecerdasan naturalis lebih baik daripada orang dewasa, karena anak pada umumnya dapat menikmati lingkungan alam secara mendalam dan tidak menganggap lingkungan sekitarnya hanyalah latar belakang dari setiap peristiwa yang ia alami. Para ahli sepakat bahwa kecerdasan dapat berubah, tetapi perubahan kecerdasan sangat dipengaruhi oleh waktu dan akan semakin terasah apabila anak tersebut tetap tinggal di lingkungan yang terus menerus memberinya rangsangan. Anak yang hidup dalam budaya agraris, petani, pemburu, dan nelayan umumnya memiliki kecerdasan naturalis yang menonjol dan kecerdasan ini bertahan hingga mereka dewasa.

\section{Penilaian Kecerdasan Majemuk}

Untuk mengetahui kompetensi dan potensi seseorang, Gardner memiliki konsep yang berbeda dari para peneliti bidang kecerdasan sebelumnya. Hampir semua tes kompetensi dan potensi yang dilakukan sebelumnya berusaha untuk menetapkan dengan tes formal yang dilakukan secara seragam dan sebagian besar instrumen pengujian amat bias karena menggunakan dua variabel kecerdasan yaitu linguistik dan logika-matematika saja. Kesimpulan tentang kompetensi dan potensi seharusnya diberikan berdasarkan pengamatan yang bijaksana dalam lingkungan sosial secara individual. Tampaknya banyak yang mencoba untuk mengetahui potensi dan kompetensi dengan desain yang sebaliknya yaitu menciptakan kebutuhan, bukan untuk memenuhi kebutuhan akan pengetahuan terhadap potensi dan kompetensi seseorang. Oleh karenanya perlu diberikan penegasan bahwa yang dilakukan bukanlah suatu tes (pengujian) melainkan penilaian untuk memperoleh 
informasi mengenai ketrampilan dan potensi dari individu dengan dua sasaran yaitu memberikan umpan balik yang bermanfaat terhadap individu yang bersangkutan dan data yang berguna kepada orang yang berada di sekitarnya tempat mereka berinteraksi. ${ }^{2}$

Begitu banyak test sekolah yang melibatkan ketrampilan tulis menulis yang menguntungkan bagi anak-anak dengan kecerdasan linguistik atau logika matematik yang tinggi. ${ }^{2,17-20}$ Ketika anak tertentu diminta memperagakan apa yang mereka ketahui hanya dengan melalui kata-kata atau angka, mereka tidak mempunyai kesempatan untuk memperlihatkan apa yang benar-benar mereka ketahui tentang suatu topik. Meski demikian jika diberi kesempatan untuk mengungkapkan apa yang telah mereka pelajari melalui kecerdasan yang lain, mereka sering bisa memperlihatkan hasil yang sangat mengagumkan. Berikut beberapa contoh jenis kegiatan yang bisa dilakukan anak di sekolah untuk menunjukkan penguasaan sebuah mata pelajaran dalam kedelapan jenis kecerdasan.

- Kecerdasan linguistik: laporan tertulis, laporan lisan, puisi, esai, drama.

- Kecerdasan logika-matematika: percobaan, tabel statistik, diagram Venn, program komputer.

- Kecerdasan spasial: menggambar, sketsa/ diagram, peta pemikiran, rekaman video

- Kecerdasan kinestetik-jasmani: acting, drama, tari, peragaan, proyek tiga dimensi.

- Kecerdasan musik: lagu, ketukan, senandung, pertunjukan musik, konseptualisasi musik.

- Kecerdasan interpersonal: diskusi kelompok, debat, simulasi kelompok, wawancara.

- Kecerdasan intrapersonal: mengisi buku harian, buku kliping, proyek independen.

- Kecerdasan naturalis: proyek ekologi, penggunaan tanaman atau hewan dalam evaluasi, kerja lapangan, penelitian tentang alam.

Jika anak tidak biasa mengerjakan tes di sekolah, temukan cara untuk menterjemahkan informasi yang ada di dalam tes ke dalam salah satu atau lebih bentuk yang dipaparkan di atas, dan kemudian dilihat apakah cara ini membantu meningkatkan kemampuan anak untuk mengungkapkan pemahamannya. Semakin banyak cara yang bisa digunakan anak untuk menunjukkan penguasaan suatu subjek, semakin besar peluang mereka untuk mencapai keberhasilan sejati. ${ }^{17}$

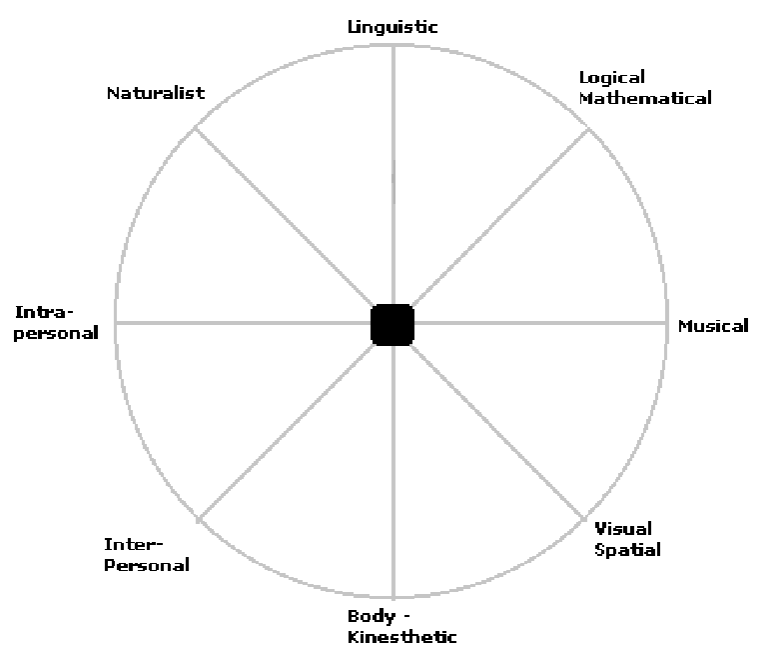

Gambar 1. Multiple Intelligence Quotient ${ }^{18}$

Dalam kenyataan, Gardner mengakui bahwa dalam mengevaluasi amatlah sulit untuk menemukan metode dan ukuran yang membantu dalam penilaian sehingga pada beberapa kasus masih tetap menghasilkan instrument tes formal. ${ }^{2}$ Untuk menggambarkan pola kecerdasan majemuk seseorang (multiple intelligence quotient) dapat dilakukan dengan bantuan check list pertanyaan kemudian memberi nilai nol (terletak di tengah lingkaran) sampai 100 (paling pinggir lingkaran). Kemudian titik tersebut dihubungkan sehingga tergambar pola dari kecerdasan majemuknya. ${ }^{19}$

Sebagian besar masyarakat berbicara bahwa semua individu bisa dinilai dengan menggunakan satu takaran, yaitu takaran seberapa pandai atau bodohnya mereka. Cara pandang ini sangat dalam tertanam pada diri kita. Tapi akhirnya kita menjadi yakin penilaian sesempit itu tidak salah tetapi mempunyai konsekuensi yang jelek dan tidak relevan dengan kompetensi dan potensi sesungguhnya. Gardner telah memaparkan delapan cara untuk melihat dunia itu. Kedelapan cara ini sama pentingnya walaupun mungkin tidak mencakup semua cara belajar yang ada, setidaknya kedelapan cara ini memberi kita gambaran yang lebih menyeluruh daripada evaluasi kita selama ini.

\section{Daftar Pustaka}

1. Lucky G A. Ulasan kritis terhadap model-model kecerdasan berbasis neuroscience: IQ, EQ, dan SQ. Journal of Psyche 2002; 1:1-16. 
2. Gardner H. Multiple Intelligences: The theory in practice. New York: Basics Book, 2003. h. 235-66

3. Soetjiningsih. Intelegensia multipel. Makalah disampaikan pada seminar menjadikan anak pintar sekaligus kreatif, Denpasar, 2 Agustus 2003.

4. Benson E. Intelligent intelligence testing. Monitor on psychology. APA Online, February 2003. h. 34: 48

5. Amin R. Menjadi remaja cerdas panduan melejitkan potensi diri. Jakarta: PT Al-Mawardi Prima, 2003. h. 110

6. Surana T. Bagaimana flashcards dan dotcards mampu meningkatkan kecerdasan anak. Didapat dari: URL: http:// www.balitacerdas.com/kembang /fd.html

7. Anonimus. Multiple intelligences. Didapat dari: URL: $h t t p: /$ /www.earthrenewal.org/ multiple\%20Intelligences 1 . htm

8. Gilman L. The theory of multiple intelligences. Didapat dari: URL: http://www.indiana.edu/intell/mitheory.shtml

9. Anonimus. Theory of multiple intelligences. Didapat dari: URL: http://www.pz.harvard.edu/sumit/misumit.htm

10. Davidson J. Multiple intelligences. Didapat dari: URL: http://www.child developmentinfo.com/learning/multiple intelligences.htm

11. Brualdi, Amy C. Multiple intelligences: Gardner's theory. ERIC Digest. Didapat dari: URL:http://www.ericdigest. org/1998-1/multiple.htm
12. Anonimus. Intelligence. Didapat dari: URL:http:// www.intelligence.htm

13. Anonimus. Triune brain theory three brains in one. Didapat dari: URL: http://www.mareshbrainswork.com/ $B 2 B / s b 7 . h t m l$

14. Pangalila, PEA. Mulailah dini. Dalam: Setiabudhhi T, Hardywinoto, editor. Anak unggul berotak prima. Jakarta: PT Gramedia Pustaka Utama, 2002. h. 1-14.

15. Meacham M. Using multiple intelligence theory in the virtual classroom. Didapat dari: URL:http://www. learningcircuits.org/2003/jun2003/elearn.html

16. Staf IQEQ. Inteligensi dan IQ. Didapat dari: URL:http:/ /www.balitacerdas.com/ kembang/iq.html

17. Amstrong T. In their own way: discovering and encouraging your child's multiple intelligences. (alih bahasa). Jakarta: PT Gramedia Pustaka Utama, 2003. h.16-53

18. Anonymus. Multiple intelligences quotient. Didapat dari: URL:http://members. optusnet.com.au/_charles57/creative/brain/miq.htm

19. Anonimus. Multiple intelligences: mengenali dan merangsang potensi kecerdasan anak. Seri Ayahbunda Mei 2003; edisi khusus: 6-116

20. Pearson EDG. Using multiple intelligences in testing and assessment. Didapat dari: URL: http://www.teacher vision.fen.com/lesson-plans-4933.tml? detoured $=1$ 